http://jmscr.igmpublication.org/home/ ISSN (e)-2347-176x ISSN (p) 2455-0450

crossref DOI: https://dx.doi.org/10.18535/jmscr/v8i4.87

Journal Of Medical Science And Clinical Research

$\underline{\text { Research Article }}$

\title{
Intrinsic and Extrinsic Factors Influencing Job Satisfaction among Nurses Working in two Selected Government Owned Hospital in Lagos, Nigeria
}

\author{
Authors \\ Olajide, Adetunmise Oluseyi ${ }^{1}$, Sowunmi, C.O. ${ }^{2}$, Adeleke, Bukola Oluwatoyin ${ }^{3}$, \\ Ojo, Ajibola ${ }^{4}$, Ogunmodede, Eunice. O. ${ }^{5}$, Ajibade, Bayo Lawal ${ }^{6}$ \\ ${ }^{1} \mathrm{RN}, \mathrm{RM}, \mathrm{RPHN}, \mathrm{BNSc}, \mathrm{MSc}$, Ladoke Akintola University of Technology, Oyo State, Nigeria \\ ${ }^{2}$ Babcock University, Ilisan-Remo, Ogun State \\ ${ }^{3}$ RN, RAE, BNSc. General Hospital Odan, Marina, Lagos Island, Nigeria \\ ${ }^{4}$ Ladoke Akintola University teaching Hospital, Ogbomoso, Oyo State \\ ${ }^{5}$ Bowen University Teaching Hospital, Ogbomoso, Oyo State, Nigeria \\ ${ }^{6}$ RN, PHD, FWACN. Ladoke Akintola University of Technology, Oyo State
}

\begin{abstract}
Background: Job satisfaction affects not only the quality of the function exercised by the nurse, job satisfaction is found to be one of the most important factors determining the quality of work, productivity, turnover and organizational performance.

Objectives: The study determined the intrinsic and extrinsic factors influencing job satisfaction among nurses working in two selected general hospital in Lagos state, Nigeria. The study was conducted among 227 Nurses at General Hospital Odan and Gbagada General Hospital Lagos State.

Method: Descriptive research design was used and simple random technique was use to recruit respondents for the study after determining the sample size of 227 using Cochran's formular. Self-administered questionnaires with reliability index of 0.806 were used to collect data from the respondents. Data was then analyzed using Statistical Software SPSS, descriptive and inferential statistics were used to answer the hypotheses and result were presented in tables and figures.

Result: The result showed a low level of job satisfaction, 100\% of the respondents were not satisfied with their monthly allowance and believed that their salaries are not commensurate with their level of competence. There is a significant relationship ; between work environment and job satisfaction; Cal. $X^{2}=6.545 ; d f=3 ; p<0.05$ ); between supervision and job satisfaction; Cal. $\left.X^{2}=130.2 ; d f=2 ; p<0.05\right)$; between organisation and administrative policy; Cal. $X^{2}=6.018$; $\left.d f=3 ; p<0.05\right)$ between interpersonal relationship and job satisfaction Cal. $X^{2}=142.7 ; d f=1$; $p<0.05)$ an between salary and job satisfaction; Cal. $\left.X^{2}=8.107 ; d f=2 ; p<0.05\right)$. This implies that job satisfaction is dependent on some extrinsic factors. The intrinsic factors identified to influence nurses job satisfaction include: $r$ achievement ; Cal. $\left.X^{2}=345.6 ; d f=3 ; p<0.05\right)$; recognition Cal. $\left.X^{2}=60.7 ; d f=3 ; p<0.05\right)$; responsibility Cal. $\left.X^{2}=617.7 ; d f=4 ; p<0.05\right)$; advancement Cal. $\left.X^{2}=265.02 ; d f=1 ; p<0.05\right)$; work, work schedule and workload; Cal. $\left.X^{2}=674.9 ; d f=5 ; p<0.05\right)$ and communication; Cal. $X^{2}=178 ; d f=2 ; p<0.05$ ).

Conclusion: The management of the hospitals should therefore be encourage improving upon nurses' remuneration, creating healthy practicing environment and improve their staffing of nurses to retain the practicing nurses and attract younger generation into the profession.

Keywords: Factors, Influencing, Job, Nurses, Satisfaction.
\end{abstract}




\section{Introduction}

Job satisfaction can be defined as positive feelings, which arise from opinion and evaluation of one's job or job experience (Locke \& Lathan 2012). On the other hand, Hirschfeld (2010) defines job satisfaction as the level that a person would like his or her job. Thus job satisfaction is the emotional reaction, which is brought about by the outcomes in comparison to the expected outcomes from the employers or service receivers. Job satisfaction is also defined as being a function of the perceived relationship between what one wants from one's job and what one perceives it is offering, influenced by the person's unique circumstances such as needs, values and expectations (Emmanuel \& Ugwa 2016).

Nurses are the most underrated people in the society especially in developing countries despite them playing a major role of providing health services, which are very essential, and taking care of people when they are hospitalized. In the nursing job, job satisfaction is very important so as to ensure the health services provided are sufficient, efficient and of high quality. (Alam and Mohammad 2009). Job satisfaction is an essential part of nurses' lives, influencing patient safety, productivity, performance, quality of care, retention, turnover, commitment to the organization and the profession (Samson-Akpan, Edet Olaide, Ojong \& Asuquo, 2015 )

The lack of job satisfaction among the nurses in Nigeria has had devastating consequences on the healthcare system and on the nation at large. Globally, the provision of health services depends on several factors such as human resources, delivery systems, and health infrastructures. In particular, the availability of human resources is adjudged to be the most important variable. (Yami, Hamza, Hassen, Jira, and Sudhakar, 2011) Job satisfaction is currently considered to be a measure that should be included in quality improvement programs. In health care organizations, it is very essential to determine factors associated with job satisfaction since this will ensure the provision of quality of care, as well as organizational efficiency, and effectiveness. Additionally, job satisfaction ensures the sustainability of health care professionals in the health care systems. Dissatisfied heath care providers are more likely to be inefficient and to provide poor quality care, and sometimes may react irrationally. Striking is known to be one of the ways that employees deploy to demonstrate their dissatisfaction with their working environment. However, striking in health care provision is the worst thing to happen as it causes disastrous outcomes. Thus there is a need to recognize the determinants of job satisfaction in our health care workers so as to avoid such occurrences in the future. A number of studies done in different parts of the world, on job satisfaction have focused on the general aspects of job satisfaction and motivation and not on actual determinants of job satisfaction (Pyrthech; 2012).

According to Habib, Sehrish, Anwar, Meerub and Saleem (2018) satisfaction of nurses' is directly linked with the patients' overall satisfaction and ultimately to quality of healthcare whereas, dissatisfaction of an employee leads to absenteeism, conflicts, and increase turnover. Unsatisfied employee report an increase intention to leave, while the influence of job satisfaction is reported to be as powerful as that of pay .Job satisfaction is a key factor of nurses' lives which can have an effect on patient protection, employee's morale, efficiency and performance, healthcare quality, retention, dedication to the organization and the job and hiring and training of new staff for the organization. Kvist, Voutilainen, Mäntynen, and Vehviläinen (2014a) also proponed that job satisfaction among nursing staff is directly proportion to quality of care. As nursing staff are satisfied from their jobs, they provide quality care to the patient. Patient outcomes and quality of care has a direct relation with nurse's job satisfaction and may be positively or negatively correlated with each other. Job satisfaction is always important among nursing because patient turnover depends upon it. 
Moreover, job satisfaction also assures the nursing retention in organization. (Butawa, 2012)

Sabria, 2013 stated that job satisfaction has various sources. These include individual's characteristics, intrinsic characteristics and extrinsic characteristics. Individual socialdemographic characteristics include age, gender, level of education marital status and professional working experience. Intrinsic characteristics include those factors related to the job such as authority, policy, procedures, security, recognition, responsibility, supervision and variety. Extrinsic characteristics are those provided by external forces. These factors are salary, allowance, supervision, working conditions, interpersonal relationships, company policy and administration

Contemporary management believes that the satisfaction of nurses from their work is the result of rational management and has a strong link with proper leadership and motivation to healthcare organizations leadership and job engagement. It is however, anticipated that when nurses are satisfied with their job, they would remain on their job and be committed to their organization (Oyibo, 2015). All these had motivated the researcher to find out about.

This study utilizes Herzberg's theory's of intrinsic and extrinsic factor of motivation to assess if it can influence nurses job satisfaction. Herzberg described factors responsible for employees' job satisfaction as intrinsic factors, which he believed are internally generated motivational variables directly related to the job content. These include work itself, responsibility, advancement, recognition, and achievement. The factors responsible for employees' job dissatisfaction were described as extrinsic factors, which he believed are externally generated variables directly related to the job surrounding. These include supervision, working conditions, company policy and administration, salary, and interpersonal relationships. The Two Factor Theory assumes on the one hand, that employees can be dissatisfied with their jobs. This often has something to do with so-called hygiene factors, such as salary and work conditions. On the other hand, employees' satisfaction has to do with socalled motivation factors. These factors have to do with development opportunities, responsibility and appreciation. Hence this study assessed the intrinsic and extrinsic factors influencing job satisfaction among nurses working in two selected general hospital in lagos state

\section{Objective of the Study \\ Broad Objectives}

The main objective of this study is to identify intrinsic and extrinsic factors influencing job satisfaction among nurses working in two selected general hospital in lagos state

\section{Specific Objectives}

1. To identify the influence of extrinsic factors (working conditions, salary, supervision, interpersonal relations and policy and administration) on job satisfaction in the two selected General Hospitals in Lagos

2. To identify the influence of intrinsic factors (work itself, achievement, recognition, responsibility and advancement) on job satisfaction in the two selected General Hospitals in Lagos

\section{Research Hypothesis}

$\mathbf{H}_{\mathbf{0}}$ : There is no significant relationship between extrinsic factors and job satisfactions among nurses in two selected General Hospital in Lagos.

$\mathbf{H}_{\mathbf{0}}$ : There is no significant relationship between intrinsic and job satisfaction factors among nurses the two selected general Hospital in Lagos

\section{Method}

\section{Research Design}

This study was carried out using descriptive research design appropriate because it helped to describe specific phenomenon or to find relationship among variables discussed.

\section{Research Setting}

This research was conducted at two General Hospital in Lagos state. 
General Hospital Gbagada was founded in in 1972 by the then Governor of Lagos state Lateef Jakande. It's also serves as annex for the Lagos state Teaching Hospital. It is located at 1, Hospital road Gbagada, Kosofe Local government. The hospital caters for everyone in her capacity. The mission of the hospital is to ensure the provision of safe, quality, affordable, adequate, equitable and accessible health services to all people in Nigeria .The hospital is the boast of the first ultramodern cardiac and renal Centre in Sub-Saharan Africa .General Hospital Gbagada specializes in providing health services in Dental, Dermatology, Dialysis, Laboratory, Medicine, LASEMS, Obstetrics and Gynaecology, Ophthalmology, Surgery, Paediatrics, Radiology, VCT and Mortuary. The hospital houses a three storey Cardiac and Renal Centre, Burns Centre, combined clinics and wards. It has 173 nurses and receives around 800 patients every day. The hospital serves as a training center for Doctors, Pharmacists, Nurses, Radiographers and Technologists across the country.

General hospital Lagos is the oldest hospital in Nigeria, was established in 1893, located between Broad Street and Marina in the central business district. The hospital is one of the several general hospitals of the Lagos State Government. It was established as a military hospital for the treatment of ill members of the British Armed forces during the colonial era. At the time of its establishment in 1893, it was the first general hospital in Nigeria. The pioneer staffs were nationalities of the British Commonwealth. On 1 October 1960, the hospital was handed over to the Federal Government and on 7 May 1967, it was finally taken over by the Lagos State Government. The Nursing School was established in 1952. Other services which commenced included General Out-Patient services, Surgery, Obstetrics and Gynecology. The Nigerian Medical Association (NMA) was established at the hospital. The hospital has served as a training center for Doctors, Pharmacists, Nurses, Radiographers and Technologists across the country. The hospital has 240 Nurses of different specialties

\section{Population of the Study}

The target populations of the study were registered nurses working in General Hospital Lagos Island and General Hospital Gbagada, Lagos not minding their race, norms, language, age, sex, tribe, marital status and working experience.

\section{Sample Size Determination}

Cochran's formula was used to determine or calculate the representative sample size

$$
\begin{aligned}
& \mathrm{n}=\frac{\mathrm{n}_{\mathrm{o}}}{1+\left(\mathrm{n}_{0}-1\right)} \\
& \text { And } \mathrm{n}_{\mathrm{O}}=\frac{\mathrm{Z}^{2} \mathrm{p}(1-\mathrm{p})}{\mathrm{e}^{2}}
\end{aligned}
$$

Where $n=$ Sample size

$\mathrm{N}=$ Study population

$\mathrm{P}=$ estimated proportion which is $50 \%$ i.e. 0.5

$\mathrm{e}=$ Margin of error which is $5 \%$ i. e 0.05

$\mathrm{Z}=$ Standard normal deviate which is 1.96 (for $95 \%$ confidence interval)

Using the above formula

$$
\begin{aligned}
\mathrm{n}_{0} & =\frac{1.96^{2} \times 0.5(1-0.5)}{0.05^{2}} \\
& =\frac{3.8416 \times 0.25}{0.0025} \\
\mathrm{n}_{0} & =\frac{0.9604}{0.0025} \\
\mathrm{n}_{0} & =384.16
\end{aligned}
$$

With our total population size of 413 nurses in the two selected general hospital will have our $\mathrm{N}$

Using the modified Cochran's formula to get exact sampling size from the two hospitals

$\mathrm{N}=413$

$\mathrm{n}_{0}=384$

$\mathrm{n}=\underline{\mathrm{n}}_{0}$

$1+\underline{\left(\mathrm{n}_{0}-1\right)}$

$\mathrm{N}$

$\mathrm{n}=\underline{384}$

$1+384-1=$

413

$384 /(1+(383 / 433))=203.8216$

$\sim 204$ 
Attrition ratio $=\underline{\text { Previous sample size } \mathrm{x} 10}$

$$
10-1
$$

$$
=\frac{204 \times 10}{9}=226.666=\simeq 227
$$

Using Proportionate ratio to determine total number of respondents to pick in each hospital; Gbagada General hospital total nurses $=173$

General Hospital Odan total nurses $=240$

Total population size $=413$ nurses

Therefore,

Gbagada General Hospital $=\underline{173 \times 227}$

$=95.08$ respondents

General Hospital Odan $=\underline{240 \times 227}$

413

$$
=131.91 \text { respondents } \simeq 132
$$

\section{Sampling Technique}

Total of 227 respondents was selected for the study using a Random sampling method, 95 questionnaires was shared at Gbagada General Hospital while 132 of the questionnaire were shared at General hospital Odan Lagos.

\section{Instrument for Data Collection}

The instrument for the collection of data for this research was self-structured and self-administered questionnaires.

\section{Pilot study}

A mini study was carried out among nurses in Ifako-Ijaiye General hospital here 23 questionnaires were shared which was $10 \%$ of the calculated sample size and was analyzed to verify the applicability of the instrument.

\section{Psychometric property of instrument: Validity and Reliability of Instrument}

\section{Validity of instrument}

The psychometric properties of the questionnaire was validated by the review of related literatures and expert in the field of nursing using face and content validity. Some modifications and correction were made before the questionnaire was administered to the target population.

\section{Reliability of instrument}

This was ascertained through analysis of the pilot test. Cronbach's Alpha was used to test the internal consistency of instrument. The Cronbach's Alpha of the items captured yielded 0.806 , depicting good reliability.

\section{Method of Data collection}

It was done in two phases. The first phase was when the researchers met with respondents to explain the purpose of the study, informed consent were signed for voluntary participation in the research. The participants were informed of their right to refuse participation in the study with no repercussions before the distribution of the questionnaires. The second phase was when the researchers distributed the questionnaires to the respondents and collected the completed questionnaires.

\section{Method of Data Analysis}

Statistical Package for the Social Sciences was used to analyze the data collected using descriptive and inferential statistics to answer research question and to test hypotheses. Results were presented in figures and tables.

\section{Ethical Considerations}

Consent was sought at two levels; the first was obtained from the ethical review committee of the health facility that was used for the study, while the second was obtained from the participating respondents before the commencement of this study. Confidentiality was maintained as elements for research will be instructed not to write their names to prevent identifications. They were also be assured that whatever information given will be treated privately, hence, they were advised to answer the questions sincerely after an informed consent has been obtained. 
Results and Discussion

Demographic Characteristics

Table 1: Socio-demographic Data of Respondents

\begin{tabular}{|l|c|c|}
\hline Age (in years) & Frequency & Percentage \\
\hline $20-30$ & 105 & 46.3 \\
$31-40$ & 70 & 30.8 \\
$41-50$ & 30 & 13.2 \\
51 \& above & 22 & 9.7 \\
Total & $\mathbf{2 2 7}$ & $\mathbf{1 0 0 . 0}$ \\
\hline Sex & Frequency & Percentage \\
\hline Male & 43 & 18.9 \\
Female & 184 & 81.1 \\
Total & $\mathbf{2 2 7}$ & $\mathbf{1 0 0 . 0}$ \\
\hline Qualifications & Frequency & Percentage \\
\hline RN & 37 & 16.3 \\
RN \&Post Basic & 127 & 55.9 \\
BNSC & 63 & 27.8 \\
MNSC & - & - \\
PhD & - & - \\
Total & $\mathbf{2 2 7}$ & $\mathbf{1 0 0 . 0}$ \\
\hline Rank & Frequency & Percentage \\
\hline NO II & 63 & 27.8 \\
NOI & 61 & 26.9 \\
SNO & 50 & 22.0 \\
PNO & 20 & 8.8 \\
CNO & 22 & 9.7 \\
ADNS & 11 & 4.8 \\
DDNS & - & - \\
& $\mathbf{2 2 7}$ & $\mathbf{1 0 0 . 0}$ \\
\hline Marital Status & Frequency & Percentage \\
\hline Single & 86 & 37.9 \\
Married & 131 & 57.7 \\
Widow/widower & 10 & 4.4 \\
Single Parent & - & - \\
Total & $\mathbf{2 2 7}$ & $\mathbf{1 0 0 . 0}$ \\
\hline Years of working Experience & Frequency & Percentage \\
\hline 0-5years & 64 & 28.3 \\
6-10years & 120 & 52.9 \\
11-15years & 33 & 14.5 \\
16years \& above & 10 & 4.4 \\
Total & $\mathbf{2 2 7}$ & -100.0 \\
\hline Shift hour duty & Frequency & Percentage \\
\hline 6hours & - & - \\
8hours & 165 & 72.7 \\
12hours & $\mathbf{2 2 7}$ & $\mathbf{1 0 0 . 0}$ \\
Total & & \\
\hline & & \\
\hline
\end{tabular}

Table 1 above show the demographic data of the respondents with majority of them 105(46.5) in 20-30 years age range, $70(30.8 \%)$ of respondents were between 31-40 years range, 30 (13.2) were between 41-50 years range while $9.7 \%$ of the respondents were 51 years \& above. Majority $184(81.1 \%)$ of the respondents were female, $43(18.9 \%)$ of them are male. $55.9 \%$ of the respondents are $\mathrm{RN} \&$ Post basic holder,27.8 are BNSC holder while about $16.3 \%$ are RN. $27.8 \%$ of the respondents are NO II, $26.9 \%$ are NO I $26.9 \%$, $22 \%, 8.8 \%$ are $\mathrm{SNO}, 9.7 \%$ are $\mathrm{CNO}$ while about $4.8 \%$ are ADNS. The majority of the respondents are married with $57.7 \%, 37.9 \%$ are single and $4.4 \%$ bare widow/widower. About $52.9 \%$ of the respondents has 6-10years of working experience, $28.2 \%$ have 0 -5years working experience, $14.5 \%$ has 11-15years working experience and 4.4 has 16years \&above working experience 
Testing of Hypothesis

Research hypothesis 1

There is no significant relationship between extrinsic factors and job satisfactions among nurses in two selected General Hospital in Lagos.

Table 2: Chi-square contingency table showing the influence of extrinsic factors on job satisfaction

\begin{tabular}{|c|c|c|c|c|c|c|c|}
\hline Variables & Extrinsic Factors of Job Satisfaction & Yes & No & Total & $\mathbf{X}^{2}$ & df & $\begin{array}{c}\text { p- } \\
\text { value }\end{array}$ \\
\hline $\begin{array}{l}\text { Working } \\
\text { Environment }\end{array}$ & $\begin{array}{l}\text { I am satisfied with my current job working } \\
\text { environment }\end{array}$ & 62 & 165 & 227 & \multirow{4}{*}{6.545} & \multirow{4}{*}{3} & \multirow{4}{*}{0.04} \\
\hline & $\begin{array}{l}\text { I am satisfied with the materials and equipment } \\
\text { made available to carry out my job }\end{array}$ & 43 & 184 & 227 & & & \\
\hline & My physical working condition are good & 43 & 184 & 227 & & & \\
\hline & $\begin{array}{l}\text { My patients co-operate because they understand } \\
\text { my working conditions }\end{array}$ & 54 & 173 & 227 & & & \\
\hline \multirow[t]{3}{*}{ Supervision } & $\begin{array}{l}\text { I am satisfied with the way my supervisor treats } \\
\text { me on my job }\end{array}$ & 108 & 119 & 227 & \multirow{3}{*}{130.2} & \multirow{3}{*}{2} & \multirow{3}{*}{0.03} \\
\hline & $\begin{array}{l}\text { I am satisfied with how my supervisor handles } \\
\text { my work-related issues }\end{array}$ & 108 & 119 & 227 & & & \\
\hline & $\begin{array}{l}\text { I am satisfied with supervisor performance } \\
\text { appraisal style }\end{array}$ & 108 & 119 & 227 & & & \\
\hline \multirow[t]{3}{*}{ Salary } & $\begin{array}{l}\text { I am satisfied with my monthly allowance at } \\
\text { current job }\end{array}$ & 220 & 7 & 227 & \multirow{3}{*}{8.107} & \multirow{3}{*}{2} & \multirow{3}{*}{0.02} \\
\hline & $\begin{array}{l}\text { My Salaries are adequate and commensurate } \\
\text { with my level of competence }\end{array}$ & 226 & 1 & 227 & & & \\
\hline & My salary is fair for my responsibilities & 226 & 1 & 227 & & & \\
\hline \multirow[t]{2}{*}{$\begin{array}{l}\text { Interpersonal } \\
\text { relationship }\end{array}$} & $\begin{array}{l}\text { I am satisfied with the existing interpersonal } \\
\text { relationship among my team at my place of } \\
\text { work }\end{array}$ & 43 & 184 & 227 & \multirow[t]{2}{*}{142.7} & \multirow[t]{2}{*}{1} & \multirow[t]{2}{*}{0.000} \\
\hline & $\begin{array}{l}\text { I am satisfied with the working relationship I } \\
\text { have with my colleagues at my place work }\end{array}$ & 170 & 57 & 227 & & & \\
\hline \multirow[t]{4}{*}{$\begin{array}{l}\text { Organization and } \\
\text { administration } \\
\text { policy }\end{array}$} & $\begin{array}{l}\text { I am satisfied with the administrative policies at } \\
\text { my place of work is fair }\end{array}$ & 44 & 183 & 227 & \multirow{4}{*}{6.018} & \multirow{4}{*}{3} & \multirow{4}{*}{0.03} \\
\hline & $\begin{array}{l}\text { I am satisfied with organization setting of my } \\
\text { current place of work }\end{array}$ & 44 & 183 & 227 & & & \\
\hline & Management implement what it says & 41 & 168 & 227 & & & \\
\hline & $\begin{array}{l}\text { I am satisfied with the management style in my } \\
\text { department }\end{array}$ & 53 & 174 & 227 & & & \\
\hline
\end{tabular}

Table 2 result show the chi-square statistic calculated for the influence of extrinsic factors (work environment, satisfaction with supervision, satisfaction with salary, interpersonal relationship and organisation and administration policy) on job satisfaction among nurses in two selected general hospitals in Lagos State. The results show that there is a significant relationship between work environment and job satisfaction; Cal. $\mathrm{X}^{2}=6.545$; $\mathrm{df}=3 ; \mathrm{p}<0.05)$; This is in line with the study carried out by Asuquo et al. (2016) in a descriptive cross-sectional study which assessed job satisfaction among nurses in Port-Harcourt Teaching Hospital, Nigeria. Poor working conditions were rated highest as cause of job dissatisfaction among the participants. Similar findings were reported by another study among Nigerian nurses by Ogbolu et al. (2015), in which the nurses expressed dissatisfaction with their working conditions and rated patient safety as 
poor in their settings. The nurses reported frustration with having to battle with gross shortage of staff, excessive workload and scarcity of resources. In a study by Waqas, Bashir, Sattar, Abdullah, Hussain, Anjum and Arshad (2014), conducted among 148 Pakistan employees from different disciplines, findings indicated that good working conditions was positively associated with job satisfaction. This implies that the working conditions such as adequate space, lighting, quality and adequate equipment, good staffing, ideal workload must be adequately catered for in order to ensure that employees are satisfied with their jobs as expressed by the findings of Waqas et al. (2014).

There is significant relationship between supervision and job satisfaction; Cal. $X^{2}=130.2$; $\mathrm{df}=2 ; \mathrm{p}<0.05$ ); This is supported by Adegoke et al. (2015) in a study to assess the factors influencing job satisfaction of midwives in rural Nigeria that reported that midwives have job dissatisfaction due to unavailability of supervisors and lack of support for their welfare. When the workplace is uncoordinated due to poor supervision, the environment becomes unhealthy for employees to function maximally, which could lead to job dissatisfaction manifesting in burnout, depression and frequent absenteeism among employees.

There is significant relationship between organisation and administrative policy; Cal. $\left.\mathrm{X}^{2}=6.018 ; \mathrm{df}=3 ; \mathrm{p}<0.05\right)$ and job satisfaction.. This is in line with Lephalala, 2016 which stated that lack of focus may lead to lack of achievement thus causing dissatisfaction

There is significant relationship between interpersonal relationship and job satisfaction Cal. $X^{2}=142.7$; $\left.d f=1 ; p<0.05\right)$ This opposed AlDossary, Vail and Macfarlane (2012) in a quantitative study which assessed the level of job satisfaction and explored factors that influence job satisfaction among Saudi Arabian nurses. The result of their study proved that interpersonal relations influence nurses' job satisfaction. The participants were satisfied with their interpersonal relations and happy with their work environment. and There is significant relationship between salary and job satisfaction/; Cal. $\mathrm{X}^{2}=8.107 ; \mathrm{df}=2$; $\mathrm{p}<0.05)$. Since $\mathrm{p}<0.05$ for all the variables, we therefore reject the null hypothesis. This is in line with Dartey-Baah and Amoako, 2011 who revealed that employees perceive their salaries to be adequate and commensurate with their level of competency, job demands and prevailing pay standards, they find their job more attractive and fulfilling which invariably leads to increase in their level of job satisfaction and productivity regardless of the presence of other unfavourable conditions. This implies that job satisfaction is dependent on some extrinsic factors such as working environment, supervision, salary, interpersonal relationship and organization and administrative policy The findings of this study is in line with Waqas, Bashir, Sattar, Abdullah, Hussain, Anjum and Arshad (2014), in a study conducted among 148 Pakistan employees from different disciplines, findings indicated that good working conditions was positively associated with job satisfaction. This is also in support with Aiken et al. (2011) who conducted a survey involving 98,116 professional nurses in 1406 different hospitals across nine European countries between 1999 and 2009. They reported high level of burnout among nurses in all the countries except Germany. The findings of this study is also consistent with Worlu and Chidozie, 2012 in a study among Nigerian employees which reported that extrinsic factors equally influence job satisfaction. The study of Dartey-Baah and Amoako (2011) among Ghanaian workers further supported the findings of this study which reported that extrinsic factors equally serving as motivators among Ghanaian workers. Similarly, Al-Dossary, Vail and Macfarlane (2012) in a quantitative study assessed the level of job satisfaction and explored factors that influence job satisfaction among Saudi Arabian nurses. The result of their study proved that interpersonal relations influence nurses' job satisfaction. A study among Jordanian nurses by Abualrub et al. (2015) established strong positive association 


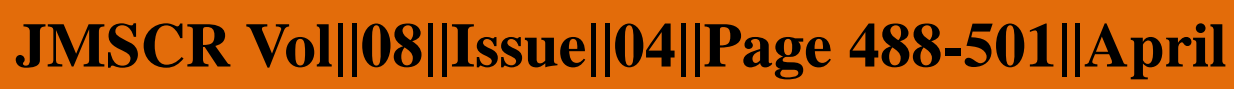

between supportive supervisor and employees' job satisfaction. This suggests that nurses with high levels of supervisory support indicated high levels of job satisfaction. The current study also confirmed the assertion of Edoho et al. (2015) which established that extrinsic factors are equally needed to motivate Nigerian nurses.

\section{Research Hypothesis 2}

There is no significant relationship between intrinsic and job satisfaction factors among nurses the two selected general Hospital in Lagos.

Table 3: Chi-square contingency table showing the influence of intrinsic factors on job satisfaction

\begin{tabular}{|c|c|c|c|c|c|c|c|}
\hline Variables & Intrinsic Factors of Job Satisfaction & Yes & No & Total & $\mathbf{X}^{2}$ & df & $\begin{array}{c}\text { p- } \\
\text { value }\end{array}$ \\
\hline \multirow{4}{*}{ Achievement } & $\begin{array}{l}\text { Individual initiatives is encouraged at my current place of } \\
\text { work }\end{array}$ & 149 & 78 & 227 & \multirow{4}{*}{345.6} & \multirow{4}{*}{3} & \multirow{4}{*}{0.000} \\
\hline & $\begin{array}{l}\text { If I could choose the career again I would make the same } \\
\text { decision }\end{array}$ & 33 & 194 & 227 & & & \\
\hline & I am satisfied with my achievement at work & 227 & - & 227 & & & \\
\hline & Have skills, knowledge and training required to do my job & 130 & 97 & 227 & & & \\
\hline \multirow{4}{*}{ Recognition } & $\begin{array}{l}\text { I am satisfied with the recognition given to for job well done } \\
\text { at my place of work }\end{array}$ & 72 & 155 & 227 & \multirow{4}{*}{60.67} & \multirow{4}{*}{3} & \multirow{4}{*}{0.000} \\
\hline & $\begin{array}{l}\begin{array}{l}\text { The associated appreciation to work increases } \\
\text { satisfaction }\end{array}\end{array}$ & 132 & 95 & 227 & & & \\
\hline & $\begin{array}{l}\text { My place of work gives enough recognition for work that's } \\
\text { well done }\end{array}$ & 132 & 95 & 227 & & & \\
\hline & My effort in my place of work are noted by my supervisor & 149 & 78 & 227 & & & \\
\hline \multirow{5}{*}{ Responsibility } & $\begin{array}{l}\text { I am satisfied with the materials and equipment made } \\
\text { available to do my work }\end{array}$ & 132 & 95 & 227 & \multirow{5}{*}{617.7} & \multirow{5}{*}{4} & \multirow{5}{*}{0.000} \\
\hline & $\begin{array}{l}\text { I am satisfied with the chance given to me to try my methods } \\
\text { at my place of work }\end{array}$ & 227 & - & 227 & & & \\
\hline & $\begin{array}{l}\text { I am satisfied with the great responsibility I am entrusted } \\
\text { with it at my place of wok }\end{array}$ & 227 & - & 227 & & & \\
\hline & $\begin{array}{l}\text { I am satisfied with the freedom given to me on how to go } \\
\text { about my work }\end{array}$ & 43 & 184 & 227 & & & \\
\hline & $\begin{array}{l}\text { I am satisfied with the recognition given to me to make } \\
\text { decision I need at my place of work }\end{array}$ & 43 & 184 & 227 & & & \\
\hline \multirow[t]{2}{*}{ Advancement } & I am satisfied with rate of advancement at my place of work & 43 & 184 & 227 & \multirow[t]{2}{*}{265.02} & \multirow[t]{2}{*}{1} & \\
\hline & I satisfied with pattern of advancement at my place of work & 43 & 184 & 227 & & & 0.000 \\
\hline \multirow{6}{*}{$\begin{array}{lr}\text { Work, } & \text { work } \\
\text { schedule } & \text { and } \\
\text { workload } & \end{array}$} & $\begin{array}{l}\text { I am satisfied with work, work schedule and workload at my } \\
\text { place of work }\end{array}$ & 43 & 184 & 227 & \multirow{6}{*}{674.9} & \multirow{6}{*}{5} & \multirow{6}{*}{0.000} \\
\hline & I am satisfied with my work routine & 43 & 184 & 227 & & & \\
\hline & $\begin{array}{l}\text { I don't have problem with availability of resources to carry } \\
\text { out work }\end{array}$ & 43 & 184 & 227 & & & \\
\hline & I am satisfied with workload at my current place of work & 43 & 184 & 227 & & & \\
\hline & I am satisfied with the work schedule of my current job & 43 & 184 & 227 & & & \\
\hline & $\begin{array}{l}\text { I am able to keep reasonable balance between my work and } \\
\text { personal life }\end{array}$ & 43 & 184 & 227 & & & \\
\hline \multirow{3}{*}{ Communication } & $\begin{array}{l}\text { I am satisfied with the level of communication between I and } \\
\text { my employer }\end{array}$ & 43 & 184 & 227 & \multirow{3}{*}{178.0} & \multirow{3}{*}{2} & \multirow[b]{3}{*}{0.000} \\
\hline & $\begin{array}{l}\text { I am satisfied with the established channel of communication } \\
\text { by my employer }\end{array}$ & 43 & 184 & 227 & & & \\
\hline & $\begin{array}{l}\text { There is adequate communication between department at my } \\
\text { place of work }\end{array}$ & 43 & 184 & 227 & & & \\
\hline
\end{tabular}


Table 3 result show the chi-square statistic calculated for the influence of intrinsic factors (achievement, recognition, responsibility, advancement, work, work schedule and workload and communication) on job satisfaction among nurses in two selected general hospitals in Lagos State. The results show that there is a significant relationship between achievement and job satisfaction; Cal. $\mathrm{X}^{2}=345.6 ; \mathrm{df}=3 ; \mathrm{p}<0.05$ ); This is in line with Velickovic et al., 2014 who revealed that nurses were reported having frustration from not achieving their goal of caring due to much time spent on routine tasks below their skills and training.

There is significant relationship between recognition and job satisfaction; Cal. $X^{2}=60.7$; $\mathrm{df}=3 ; \mathrm{p}<0.05)$; The result of the study supported the findings of Khunou, and Davhana-Maselesele (2016) which revealed that the participants were having poor job satisfaction due to lack of recognition and appreciation for job well done. When employees are appreciated for job well done, it serves as source of positive feedback to them thereby increasing their level of confidence,

There is significant relationship between responsibility and job satisfaction; Cal. $\mathrm{X}^{2}=617.7$; $\mathrm{df}=4 ; \mathrm{p}<0.05)$ This is in line with Azim, Haque and Chowdhury,2013 which stated that allowing nurses to practice at the level of their expertise and making decisions about patients' care increase their motivation and thus their level of job satisfaction. More so, professional autonomy is central to cultivation of passion for excellence and professional development among nurses.

There is significant relationship between advancement and job satisfaction Cal. $X^{2}=265.02$; $\mathrm{df}=1 ; \mathrm{p}<0.05)$. This is line with Masum et al., 2016 which revealed that advancement opportunities are very critical to employees' job satisfaction and commitment to the organizational goals.

There is significant relationship between work, work schedule and workload and job satisfaction; Cal. $\left.\mathrm{X}^{2}=674.9 ; \mathrm{df}=5 ; \mathrm{p}<0.05\right)$. This result is line with $\mathrm{Li}$ et al., 2013 which revealed in a study that nurses from Germany, France, Poland, Italy, Netherlands, Belgium, Slovakia and China reported having poor job satisfaction and frustration with nursing profession due to excessive workload.

There is significant relationship between communication; Cal. $\left.\mathrm{X}^{2}=178 ; \mathrm{df}=2 ; \mathrm{p}<0.05\right)$. Since $p<0.05$ for all the variables, we therefore reject the null hypothesis. This result is in agreement with Sammons, 2013 who revealed that poor communication create a lot of confusion at the work place and by the end of the day the achievement is not as expected, thus in the long run it leads to dissatisfaction among the workers.

The outcome of this study implies that job satisfaction is dependent on some intrinsic factors such as achievement, recognition, responsibility, advancement, work, work schedule and workload and communication have positive influence on the level of job satisfaction among nurses working in two selected General Hospital in Lagos State. This agreed with the findings of Wanjohi \& Maringi (2013) which revealed intrinsic factors such as motivating factors that bring about satisfaction through fulfilling the individual needs for personal growth and meaning and relate directly to the individual's job and facilitate the level of job satisfaction. This is consistent with Rouleau, Fournier, Philibert, Mbengue, and Dumont (2012) in a study to examined the professional lives and job satisfaction of midwives in Senegal which reported that more than half of the participants (55\%) have emotional exhaustion and job dissatisfaction which was positively correlated with lack of opportunity for advancement and professional training. Tessema, Ready and Embaye, (2013) also revealed that recognition is the positive acknowledgement of employees' exceptional performance or achievement, which have significant bearing on employees' overall level of job satisfaction.

This is in line with Bahalkani, Kumar, Lakho, Mahar and Majeed (2011) who reported gross job dissatisfaction among Pakistan nurses due to lack of involvement of nurses in decision making, and 
under-achievement as a result of doing more of improper and non-nursing task and poor career structure. Similar findings have been reported by Adegoke et al. (2015) and Hoonakker et al. (2013) which indicate clearly that involvement of employees in decision-making at all levels by employers serve as a strong motivator to work leading to job satisfaction. This is also in consistent with Miyata, Arai and Suga (2013), in a survey across 10 hospitals involving 1425 nurses in Japan explored the perception of nurses on the recognition behaviours of their nurse manager and established its relationship to the nurse sense of coherence (SOC). Their findings cited recognition of nurses' achievement as potential factor that could enhance nurse SOC leading to reduced burnout and increased job satisfaction.

\section{Recommendations}

Based on the findings of this study, the following are recommended.

Policy makers should propose and implement interventions to increase levels of job satisfaction among professionals nurses since job satisfaction has a strong correlation with job performance, it is imperative to reinforce relevant human resources polices, improving working conditions and compensation.

Nurses Priority should be given to improving relationships between management and staff and increasing decision-making latitude among staff members. Developing staff and empowering them to make decisions about their work is necessary to achieve quality outcomes. It is recommended that employees' job be redesigned to have a scope of enrichment and be of interest.

Impact on services Continuous service evaluations and monitoring of job satisfaction can be useful to determine aspects of the services that need improvement. Involving staff in a cooperative, team approach will allow for consideration of ways to improve aspects relating to job satisfaction. Improving the work environment so that it provides a context in line with the aspirations of healthcare professionals is likely to increase job satisfaction and consequently have a positive effect on individual, organizational and quality of health care services.

\section{Limitation of the Study}

Structured questionnaire was used for the study which may have limited the information respondents want to provide if not captured in the questionnaire. Secondly, there could be respondents' bias from the nurses who may not want to give the actual response of the situation of the hospital.

\section{Conclusion}

Based on the outcome of the study, it is recommended that

1. Hospital management should keep vivid record of nurses' performance and poised to recognize, commend, reward both in kind and cash such as bonuses, and promotion for job well-done, ethical conduct and excellence.

2. Hospital management should improve upon staffing of nurses. Hospital management having determined through adequate consultations the size of staff needed for efficient nursing care, employment should be done promptly and accordingly. They should also be at alert to replace staff in the advent of resignation, retirement, transfer or death so as to circumvent further staff shortage.

3. Management should focus on nurses' job enrichment by providing them with stimulating and interesting work that challenge and motivate them. Nurses should equally be given autonomy over nursing practice.

4. Hospital management should be explicit and transparent on their policies and administrations. Nurses should be given job description with clearly delineated jurisdiction while taking into cognizance their competency, experience, and educational training.

5. Good organizational culture should be created and sustained through regular staff meetings, orientation, seminars and workshops to socialize 
and educate employees on professional and ethical practices.

6. Nurses' opinion should be respected by other professionals. Nurses professional practice judgment should not be relegated on the bases of sentiments. There is need for the hospital management to employ an individualistic management approach to promote satisfaction among nurses. The individual approach will also enlighten management about the challenges confronting individual nurses. This would eschew incidence of rivalry, witch-hunting and lack of teamwork which can lead to sabotage and compromised quality care. Hospital management should also hold regular meetings and seminars to educate and acquaint both staff on hospital policies and appropriate ways of channelling complaints. There must be equity and justice in the management of personnel so as to discourage outburst of grievances between nurses and management. This is paramount because until nurses are satisfied with their job, they cannot be poised to maximise their potentials. Furthermore, for hospital management to have a stable nursing workforce, they must enable conditions that promote positive workplace climate. Developing a positive workplace climate and a learning organization in the hospital naturally would foster job satisfaction among nurses.

\section{Nursing and Midwifery Council of Nigeria (NMCN)}

Nursing and Midwifery Council of Nigeria should:

1. Liaise with the Ministry of Health both at the Federal, State and Local government levels, To ensure formulation of policies that will represent the interest of the Nigerian nursing workforce. This could be rightly achieved through adequate consultation with nurses to know their plights and demands and lobby the appropriate authorities to ensure that nurses' demand and welfare are given due consideration and provided for.

2. Visit healthcare organizations periodically to ensure that they are complying with the standard of practice such as accepted nurse-patient ratio, service entry point, etc. The NMCN should constitute a unit that will be saddled with the sole responsibilities of visiting healthcare institutions at all levels to assess their level of compliance with the constituted standard and ethics of nursing profession.

3. Ensure that nurses' complaints are acknowledged and channeled to the appropriate bodies for immediate action so as to ensure a satisfied nursing workforce. This is achievable through one on-one consultations with nurses to know their level of job satisfaction and factors impeding their professional practice.

\section{Conflict of Interest}

The Authors declare that there is no conflict of interest

\section{References}

1. Abu Al Rub, R., El-Jardali, F., Jamal, D., \& Al-Rub, N. A. (2015). Exploring the Relationship between Work Environment, Job satisfaction, and Intent to Stay of Jordanian Nurses in Underserved areas. Applied Nursing Research.

2. Adegoke, A. A., Atiyaye, F. B., Abubakar, A. S., Auta, A., \& Aboda, A. (2015).Job satisfaction and retention of midwives in rural Nigeria. Midwifery, 31(10), 946-956.

3. Aiken, L. H., Sloane, D. M., Clarke, S., Poghosyan, L., Cho, E., You, L., \& Aungsuroch, Y. (2011). Importance of work environments on hospital outcomes in nine countries. International Journal for Quality in Health Care, 23(4), 357-364.

4. Alam, Q. \& Mohammad, K., (2016)The shape of the relationship between salary and job satisfaction: A field study. Far East Journal of Psychology and Business, 7(3), 1- 12. Retrieved from http://www.fareastjournals.com/ Default.aspx

5. Al-Dossary, R., Vail, J., \& Macfarlane, F. (2012). Job satisfaction of nurses in a 
Saudi Arabian university teaching hospital: A cross-sectional study. International Nursing Review, 59(3), 424430.

6. Asuquo, E. O., Imaledo, J. A., ThompOnyekwelu, C., Abara, N. L., \& Agugua, C. C. (2016). Job satisfaction among nurses in the University of Port-Harcourt Teaching Hospital, PortHarcourt, Nigeria. Int. J. Curr. Res. Med. Sci, 2(7), 59-70.

7. Azim, M. T., Haque, M. M., \&Chowdhury, R. A. (2013). Gender, marital status and job satisfaction. An empirical study.International Review of Management and Business Research, 2(2), 488.

8. Bahalkani, H. A., Kumar, R., Lakho, A. R., Mahar, B., Mazhar, S. B., \& Majeed, A. (2011).Job satisfaction in nurses working in tertiary level health care settings of Islamabad, Pakistan. Journal of Ayub Medical College Abbottabad, 23, 130-133.

9. Dartey-Baah, K., \&Amoako, G. K. (2011). Application of Frederick Herzberg's TwoFactor theory in assessing and understanding employee motivation at work: a Ghanaian Perspective. European Journal of Business and Management, 3(9), 1-8.

10. Edoho, S. A. P., Bamidele, E., Neji, O. I., \& Frank, A. E. (2015). Job satisfaction among nurses in public hospitals in Calabar, Cross River State Nigeria. American Journal of Nursing, 4(4), 231237. .

11. Emmanuel U., \& Charity, U., (2016) A Narrative Review of Factors Affecting Job Satisfaction among Nurses in Africa: Hospital Practices and Research available on doi: 10.20886/hpr-019379.

12. Hirschfeld, R.R. (2010). Validity Studies. Does Revising the Intrinsic and Extrinsic Subscales of the Minnesota Satisfaction Questionnaire Short Form Make a
Difference? Educational Psychological Measurement, 60, 255-270.

13. Khunou, S. H., \& Davhana-Maselesele, M. (2016). Level of job satisfaction amongst nurses in the North-West Province, South Africa: Post occupational specific dispensation. Crationis, 39(1), 1-10.

14. Li, B., Bruyneel, L., Sermeus, W., Van den Heede, K., Matawie, K., Aiken, L., \& Lesaffre, E. (2013). Group-level impact of work environment dimensions on burnout experiences among nurses: a multivariate multilevel probit model. International Journal of Nursing Studies, 50(2), 281291.

15. Locke and Lathan (2012) Extrinsic and intrinsic job factors: Motivation and satisfaction in a developing Arab country the case of Lebanon. The Journal of Applied Management and Entrepreneurship, 19, 66-82. Retrieved from http://secure.business.nova.edu/JAME/

16. Masum, A. K. M., Azad, M. A. K., Hoque, K. E., Beh, L. S., Wanke, P., \& Arslan, Ö. (2016). Job satisfaction and intention to quit: an empirical analysis of nurses in Turkey. PeerJ, 4, e1896.

17. Miyata, C., Arai, H., \&Suga, S. (2015). Characteristics of the nurse manager's recognition behavior and its relation to sense of coherence of staff nurses in Japan. Collegian, 22(1), 9-17.

18. Ogbolu, Y., Johantgen, M. E., Zhu, S., \& Johnson, J. V. (2015). Nurse reported patient safety in low-resource settings: a cross-sectional study of $\mathrm{MNCH}$ nurses in Nigeria. Applied Nursing Research, 28(4), 341-346.

19. Oyibo, S. S. (2015). Factors influencing job satisfaction among nurses in Ahmadu Bello University Teaching Hospital (ABUTH), Zaria, Kaduna State, Nigeria

20. Rouleau, D., Fournier, P., Philibert, A., Mbengue, B., \& Dumont, A. (2012). The effects of midwives' job satisfaction on 
burnout, intention to quit and turnover: a longitudinal study in Senegal. Human Resources for Health, 10(1), 1.

21. Tessema, M. T., Ready, K. J., \&Embaye, A. B. (2013). The effects of employee recognition, pay, and benefits on job satisfaction: Cross country evidence. Journal of Business and Economics, 4(1), 1-12.

22. Veličković, V. M., Višnjić, A., Jović, S., Radulović, O., Šargić, Č., Mihajlović, J.,\& Mladenović, J. (2014). Organizational commitment and job satisfaction among nurses in Serbia: A factor analysis. Nursing Outlook, 62(6), 415-427.

23. Waqas, A., Bashir, U., Sattar, M. F., Abdullah, H. M., Hussain, I., Anjum, W., \& Arshad, R. (2014). Factors Influencing Job Satisfaction and Its Impact on Job Loyalty. International Journal of Learning and Development, 4(2), 141-161.

24. Worlu, R. E., \&Chidozie, F. C. (2012). The validity of Herzberg's dual-factor theory on job satisfaction of political marketers. African Research Review, 6(1), 39-50. 